\title{
Precise Exchange of the Helper-Component Proteinase Cistron Between Soybean mosaic virus and Clover yellow vein virus: Impact on Virus Viability and Host Range Specificity
}

\author{
Y. Wang, ${ }^{1,2}$ W. Xu, ${ }^{1}$ J. Abe, ${ }^{3}$ K. S. Nakahara, ${ }^{3}$ and M. R. Hajimorad ${ }^{1, \dagger}$ \\ ${ }^{1}$ Department of Entomology and Plant Pathology, University of Tennessee, Knoxville, TN 37996, U.S.A. \\ 2 Jilin Academy of Agricultural Sciences, Changchun 130033, Jilin, China \\ ${ }^{3}$ Research Faculty of Agriculture, Hokkaido University, Sapporo 060-8589, Japan \\ Accepted for publication 3 September 2019.
}

\begin{abstract}
Soybean mosaic virus and Clover yellow vein virus are two definite species of the genus Potyvirus within the family Potyviridae. Soybean mosaic virus-N (SMV-N) is well adapted to cultivated soybean (Glycine max) genotypes and wild soybean (G. soja), whereas it remains undetectable in inoculated broad bean (Vicia faba). In contrast, clover yellow vein virus No. 30 (ClYVV-No. 30) is capable of systemic infection in broad bean and wild soybean; however, it infects cultivated soybean genotypes only locally. In this study, SMV-N was shown to also infect broad bean locally; hence, broad bean is a host for SMV-N. Based on these observations, it was hypothesized that lack of systemic infection by SMV-N in broad bean and by ClYVV-No. 30 in cultivated soybean is attributable to the incompatibility of multifunctional helper-component

proteinase (HC-Pro) in these hosts. The logic of selecting the HC-Pro cistron as a target is based on its established function in systemic movement and being a relevant factor in host range specificity of potyviruses. To test this hypothesis, chimeras were constructed with precise exchanges of $\mathrm{HC}$ Pro cistrons between SMV-N and ClYVV-No. 30. Upon inoculation, both chimeras were viable in infection, but host range specificity of the recombinant viruses did not differ from those of the parental viruses. These observations suggest that (i) HC-Pro cistrons from SMV-N and CIYVV-No. 30 are functionally compatible in infection despite 55.6 and $48.9 \%$ nucleotide and amino acid sequence identity, respectively, and (ii) HC-Pro cistrons from SMV-N and CIYVV-No. 30 are not the determinants of host specificity on cultivated soybean or broad beans, respectively.
\end{abstract}

The Potyviridae represent the largest family of plant RNA viruses and contain eight genera, the largest of which, Potyvirus, has $>140$ definite species as well as a significant number of tentative species (Adams et al. 2012; Gibbs and Ohshima 2010; Wylie et al. 2017). Particles of potyviruses are flexuous filaments containing a singlestranded RNA genome of positive polarity possessing a covalently linked 5'-terminal viral protein (viral protein genome-linked [VPg]) and a $3^{\prime}$-terminal poly(A) tail (Wylie et al. 2017). Expression of a potyviral genome results in the production of a number of multifunctional proteins, including helper-component proteinase (HC-Pro) (Revers and Garcia 2015). In addition, a small open reading frame (i.e., pipo) embedded in the $\mathrm{P} 3$ cistron encodes a protein in the +2 frame that is involved in virus movement and plays a part in virulence in specific potyviral pathosystems (Atsumi et al. 2016; Choi et al. 2013; Chung et al. 2008; Vijayapalani et al. 2012; Wen and Hajimorad 2010).

A number of potyviruses have a very narrow host range, whereas others are capable of infecting plant species belonging to more than 30 plant families (Adams et al. 2012). The underlying molecular

†Corresponding author: M. R. Hajimorad; mrh@utk.edu

Current address of W. Xu: Jilin Academy of Agricultural Sciences, Changchun 130033, Jilin, China

Funding: This project was supported in part by the University of Tennessee Agricultural Experimental Station in Knoxville, Tennessee, and the Tennessee Soybean Promotion Board. Y. Wang was supported in part by the Science and Technology Bureau of Jilin Province, China (grant 20180201013NY).

*The $\boldsymbol{e}$-Xtra logo stands for "electronic extra" and indicates that four supplementary figures, three supplementary tables, and one supplementary data file are published online.

The authors declare no conflict of interest.

(c) 2020 The American Phytopathological Society mechanism(s) of host range and host specificity of plant viruses in general is largely unknown; however, this has been attributed to nonhost resistance to some extent (Hull 2014). Nevertheless, the presence of a specific resistance gene(s) in a host, dominant $(R$ gene) or recessive, may also restrict viruses to the site of inoculation via an active or a passive mechanism (Whitham and Hajimorad 2016). It should be noted that in the majority of studies addressing host range specificity, virologists have taken advantage of isolates of the same virus species with a contrasting level of adaptations in order to map the viral determinants (Calvo et al. 2014; Carbonell et al. 2013; Chen et al. 2008; Poulicard et al. 2012; Ryu et al. 1998; Sardaru et al. 2018; Schoelz and Shepherd 1988; Suehiro et al. 2004; Tan et al. 2005; Vassilakos et al. 2015). However, in the absence of isolates of the same virus species with a differential level of pathogenicity on the targeted host, virologists have successfully used two different virus species from the same genera in a few instances (Hilf and Dawson 1993; Mise et al. 1993; Padgett and Beachy 1993; Padgett et al. 1997). For example, the host range determinant of Tobacco mosaic virus (TMV) on $N$-genotype tobacco was mapped by taking advantage of two tobamovirus species (Padgett and Beachy 1993; Padgett et al. 1997). It should be noted that TMV-Ob that served as a virulent tobamovirus on $\mathrm{N}$ genotype tobacco was subsequently named Obuda pepper virus and classified as a distinct species within the genus Tobamovirus (Gibbs et al. 2004; Hull 2014). Two features of the TMV/N-genotype tobacco pathosystem led to the success of this approach. First, TMV and obuda pepper virus were both capable of differentially infecting host plant species belonging to the same plant genus (i.e., Nicotiana). Second, the underlying mechanism restricting TMV to move systemically in this pathosystem was the presence of a single $R$ gene ( $N$ gene) conferring active resistance against the avirulent TMV.

In general, adaptation of plant viruses to a new host species is complex, requiring mutation(s) in multiple viral-encoded proteins involved in replication, cell-to-cell, and long-distance movement 
(Dawson and Hilf 1992). The observation that host jump of viruses is a rare phenomenon provides additional evidence that viruses must overcome many hurdles to overcome host species barriers (Dawson and Hilf 1992; Vassilakos et al. 2015; Webby et al. 2004).

Soybean mosaic virus (SMV) and Clover yellow vein virus (ClYVV) are both definite Potyvirus species members (Wylie et al. 2017). However, SMV has a much narrower host range relative to that of ClYVV (Bos 1972; Hajimorad et al. 2018; Sasaya et al. 1997). Nevertheless, both of these viruses are incapable of systemically infecting a number of plant species within the family of Leguminosae. SMV is well adapted to cultivated soybean (Glycine $\max )$ as well as wild soybean $(G$. soja), whereas it is undetectable from experimentally inoculated broad bean (Vicia faba) (Bos 1972; Cheng et al. 2010; Golnaraghi et al. 2004; Hunst and Tolin 1982; Khatabi et al. 2012; Seo et al. 2009). In contrast, CIYVV is capable of systemic infection in broad bean and wild soybean, whereas infection in inoculated cultivated soybean remains localized (Abe et al. 2019; Bos et al. 1977; Foster and Musgrave 1985; Masuta et al. 2000; Munro 1981; Nakahara et al. 2011; Sasaya et al. 1997). To date, only a single report of natural infection of ClYVV in cultivated soybean has been reported worldwide (Shin et al. 2014). Localized infection of ClYVV in cultivated soybean was attributed to the presence of one major quantitative resistance locus containing recessive gene(s) restricting systemic movement of the virus in mechanically but not graftinoculated cultivated soybean; however, the viral determinant(s) interacting with this resistance locus remains unknown (Abe et al. 2019). Thus, based on the findings of Abe et al. (2019) and the presence of a naturally occurring ClYVV strain infecting systemically cultivated soybeans (Shin et al. 2014), it appears that the underlying mechanism limiting ClYVV to inoculated soybean leaves does not involve nonhost resistance. In the case of the SMV/broad bean pathosystem, the inoculated plants remain asymptomatic and the virus has not been detected from such plants (Golnaraghi et al. 2004; Hunst and Tolin 1982). Furthermore, to our knowledge, there is no published record of systemic infection of broad bean by a strain of SMV to date. Thus, it is unknown whether the underlying mechanism(s) leading to the lack of detectability of SMV in inoculated broad bean is a consequence of nonhost or hostspecific resistance. In a number of pathosystems involving viruses and host genotypes harboring $R$ genes (or recessive genes), the phenotype of resistance, which is symptomless, is indistinguishable from nonhost resistance (Adams et al. 1986; Bendahmane et al. 1999; Hajimorad and Hill 2001; Ishibashi et al. 2009).

The aim of this study was to determine whether broad bean is a host or nonhost to SMV and also to determine whether reciprocal exchanges of HC-Pro between SMV strain N (SMV-N) and ClYVV strain No. 30 (ClYVV-No. 30) lead to viable viruses with impacts on host range specificity. HC-Pro is a multifunctional potyviral protein that is involved in many activities, including, but not limited to, cellto-cell and long-distance movement, pathogenicity, and virulence (Cronin et al. 1995; Hajimorad et al. 2008; Khatabi et al. 2013; Lopez-Moya et al. 2009; Rojas et al. 1997; Sáenz et al. 2002; Valli et al. 2018; Wen et al. 2013). Furthermore, it has been shown that HC-Pro is a relevant potyviral factor in host range specificity (Carbonell et al. 2012; Sáenz et al. 2002). The hypotheses tested were as follows: (i) broad bean is a host to SMV-N; however, SMV-N is incapable of systemic movement in this host; and (ii) multifunctional HC-Pro citrons from SMV-N and ClYVV-No. 30 play a role in host range specificity and virulence of these viruses in cultivated soybean and broad bean, respectively. Well-characterized molecularly cloned SMV-N and ClYVV-No. 30 (GenBank accessions D00507.2 and NC_003536, respectively), with or without uidA gene expressing $\beta$-glucuronidase (GUS), were utilized in this study to construct chimeras and to test the above hypotheses (Abe et al. 2019; Masuta et al. 2000; Wang et al. 2006). The results show that HC-Pro cistrons from SMV-N and ClYVV-No. 30 are functionally compatible in infection; however, they are not the determinants of host specificity on cultivated soybean or broad bean.

For the purposes of this communication, a plant is defined as a host when it supports virus replication at least at the cellular level (Hull 2014). Pathogenicity is defined as the capability of a virus to move systemically in a given host to cause systemic infection in noninoculated leaves regardless of the phenotypes induced (Shaner et al. 1992). Virulence is defined as the ability of a virus to overcome restriction in systemic movement owing to the presence of a known resistance factor in a host (Shaner et al. 1992).

\section{MATERIALS AND METHODS}

Viruses, host genotypes, and inoculation. The full-length infectious cDNA clones of SMV-N or ClYVV-No. 30, with or without the uidA gene, were used in this study (Abe et al. 2019; Masuta et al. 2000; Wang et al. 2006). SMV-JL1 and SMV-JL3 were originally isolated from infected field-grown soybeans in Jilin province of China. SMV-JL1 was subsequently maintained in soybean, whereas an infectious cDNA clone representing SMV-JL3 was generated (unpublished data) and progeny viruses derived from the molecularly cloned SMV-JL3 in soybean were used as an inoculum source in this study. SMV-G7 and SMV-G7d were previously described (Hajimorad et al. 2003). Cultivated soybean (G. max) genotypes Williams, Lee68, and recombinant inbred line (RIL) 943 (-3gG2) (Bernard et al. 1991; Hayes et al. 2004); wild soybean (G. soja) lines B01167, T106, and B04158 (obtained from the LegumeBase at https://www.legumebase.brc.miyazaki-u.ac.jp/); and broad bean ( $V . f a b a$ L.) cultivars Windsor, Robin Hood, LiaoN, and SanD were used in this study. Seeds of all broad bean cultivars were purchased from commercial sources. Virus-free seeds of cultivated soybeans were obtained from virus-indexed plants. To establish infection with plasmid DNA, fully expanded primary leaves were biolistically inoculated as described previously (Hajimorad et al. 2003, 2008). To inoculate plants mechanically, progeny viruses in sap extract from biolistically inoculated and systemically infected leaf tissues of soybean Williams or broad bean Windsor in $10 \mathrm{mM}$ of phosphate buffer, $\mathrm{pH}$ 7.0, were applied manually to carborundumdusted fully developed primary leaves of targeted plants. The inoculated plants were kept in a growth chamber at $22^{\circ} \mathrm{C}$ with a $16-\mathrm{h}$ photoperiod. Histochemical assay of GUS expression in infected tissues was performed as described by Wen and Hajimorad (2010). ClYVV was detected by enzyme-linked immunosorbent assay (ELISA) as described by Abe et al. (2019), whereas detection of SMV coat protein (CP) in infected tissues was done as described by Malapi-Nelson et al. (2009).

Construction of SMV-N- and CIYVV-No. 30-derived chimeras with precise exchanges of HC-Pro cistron. SMVN/ClYVV-No. 30 HC-Pro and ClYVV-No. 30/SMV-N HC-Pro chimeras with precise exchanges of HC-Pro cistrons between the two parental viruses (SMV-N and ClYVV-No. 30) were constructed by using fusion-PCR as described by Charlier et al. (2003) and primers as listed in Supplementary Table S1. PrimeSTAR HS DNA polymerase Premix (Takara Bio, Madison, WI) was used in all amplification reactions. The nature of viral constructs with a precise exchange of HC-Pro was confirmed by Sanger sequencing. Details of construction of the chimeras and sequencing are presented in Supplementary Data File S1. Oligonucleotides were used for construction of chimeras as well as sequencing are listed in Supplementary Table S1.

RNA extraction, reverse transcription PCR, Sanger sequencing, and bioinformatics. Total RNA was isolated from systemically infected leaves from biolistically inoculated plants using an RNeasy plant mini kit (Qiagen, Valencia, CA). To verify the stability of the chimeras in planta, the genome of progeny viruses was reverse transcribed using random primer in the presence of SuperScript reverse-transcriptase III as instructed by the manufacturer (Invitrogen, Carlsbad, CA). PCR amplification of the entire HC-Pro cistron was done using oligonucleotide primer 
sets outlined in Supplementary Table S1 in the presence of ExTaq polymerase (Takara Bio). The resultant amplicons were purified with a QIAquick PCR Purification Kit (Qiagen) and sequenced using specific primers (Supplementary Table S1). Sequencing was done at the University of Tennessee DNA Sequencing Facility and sequences were edited and analyzed using Vector NTI (Invitrogen). Determination of the percent identity of nucleotides and predicated amino acids was performed according to the Jotun Hein method (de Groot et al. 2008).

\section{RESULTS}

SMV-N infects broad bean locally but fails to move systemically. To demonstrate whether broad bean serves as a host
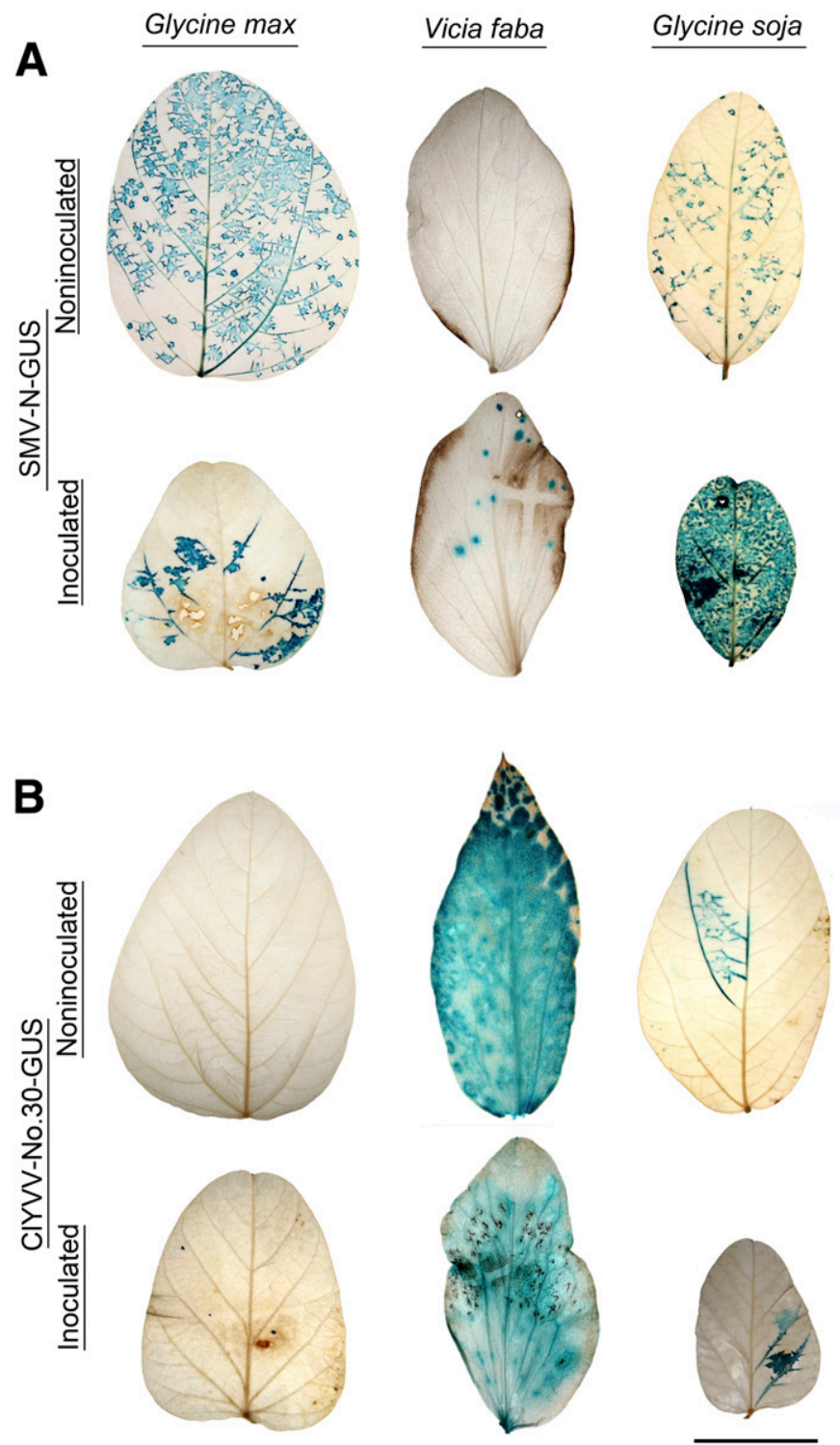

Fig. 1. $\beta$-glucuronidase (GUS) histochemical analysis of $\mathbf{A}$, soybean mosaic virus-N (SMV-N) GUS or B, clover yellow vein virus-No. 30 (ClYVV-No. 30) GUS infection in biolistically inoculated or noninoculated leaves from soybean (Glycine max) cultivar Williams, broad bean (Vicia faba) cultivar Windsor, or wild soybean ( $G$. soja) line B01167. For inoculation, a full-length infectious cDNA clone of each of the viruses harboring GUS was delivered biolistically into fully developed attached primary leaves of approximately 2week-old seedlings maintained at $22^{\circ} \mathrm{C}$. Leaves were analyzed histochemically for GUS expression at 21 days postinoculation. Note that SMV-N GUS is incapable of systemic infection in broad bean Windsor, whereas ClYVV-No. 30 GUS is incapable of systemic movement in soybean cultivar Williams. Scale bar $=2 \mathrm{~cm}$. to SMV, the attached primary leaves of cultivar Windsor were biolistically inoculated with SMV-N GUS. Figure 1A shows that based on expression of GUS, SMV-N GUS caused local infection in the inoculated leaves, albeit to a few foci; however, no GUS expression was observed in adjacent veins at 21 days postinoculation (DPI). Furthermore, no GUS expression was detected in noninoculated leaves (Fig. 1A). It should be noted that SMV-N GUS was detected in veins of inoculated leaves of both cultivated soybean Williams and wild soybean line B01167 and systemically moved efficiently in both of these hosts (Fig. 1A). SMV-N also systemically infected two other wild soybean lines, T106 and B04158 (data not shown), demonstrating that it is well adapted to this host species. To rule out the possibility that the inability of SMV-N GUS to move systemically in broad bean Windsor is a consequence of tagging with uidA gene (German-Retana et al. 2000), broad bean cultivar Windsor was also inoculated with SMV$\mathrm{N}$ without the uidA gene (GUS). However, the inoculated broad bean cultivar Windsor, similar to those inoculated with SMV-N GUS, also remained asymptomatic and virus was not detectable in noninoculated leaves by ELISA (Table 1). To demonstrate that the lack of systemic infection in Windsor by SMV-N is not cultivar specific, broad bean cultivar Robin Hood was also inoculated; however, no systemic infection occurred (Table 1). To demonstrate that the inability of SMV-N to infect broad bean cultivars is not SMV strain specific, other strains of SMV were also inoculated to broad bean cultivar Windsor as well as Chinese cultivars LiaoN and SanD. Only SMV-JL3 was detected in the upper noninoculated leaves above the inoculated leaves in a single LiaoN plant by ELISA; however, virus was not recovered from these tissues by back-inoculation onto a susceptible soybean (Table 2). Furthermore, SMV-JL3 was not detected in leaves located at the top of this plant by ELISA either. All of the other SMV strains (SMV-G7, SMV-G7d, and SMV-JL1) failed to move systemically in all of the

TABLE 1. Systemic responses of host genotypes to inoculation with soybean mosaic virus-N (SMV-N) or clover yellow vein virus No. 30 (ClYVV-No. 30) ${ }^{\mathrm{a}}$

\begin{tabular}{|c|c|c|c|c|}
\hline \multirow[b]{3}{*}{ Virus } & \multicolumn{4}{|c|}{ Host genotype $(n)^{\mathrm{b}}$} \\
\hline & \multirow{2}{*}{$\frac{\text { Glycine max }}{\text { Williams }}$} & \multicolumn{2}{|c|}{ Vicia faba } & \multirow{2}{*}{$\frac{\text { G. soja }}{\mathrm{B} 01167}$} \\
\hline & & Windsor & Robin Hood & \\
\hline SMV-N & $19 / 32$ & $0 / 14$ & $0 / 27$ & $10 / 10$ \\
\hline ClYVV-No. 30 & $0 / 28$ & $8 / 8$ & $22 / 24$ & $13 / 13$ \\
\hline
\end{tabular}

a Plants were inoculated biolistically or mechanically.

b Total number of plants systemically infected/total numbers of plants mechanically inoculated on primary leaves with sap extract from infected tissues or biolistically inoculated with infectious cDNA clones. Plants were evaluated for presence of systemic symptoms at 21 days postinoculation. Asymptomatic plants were assayed by enzyme-linked immunosorbent assay.

TABLE 2. Systemic responses of host genotypes to mechanical inoculation with various strains of soybean mosaic virus (SMV)

\begin{tabular}{|c|c|c|c|c|c|}
\hline \multirow[b]{3}{*}{ Virus } & \multicolumn{5}{|c|}{ Host genotype $(n)^{\mathrm{a}}$} \\
\hline & \multirow{2}{*}{$\frac{\text { Glycine max }}{\text { Williams }}$} & \multicolumn{4}{|c|}{ Vicia faba } \\
\hline & & Windsor & Robin Hood & LiaoN & SanD \\
\hline SMV-G7 & $12 / 24$ & $0 / 35$ & $0 / 30$ & $\mathrm{ND}^{\mathrm{b}}$ & ND \\
\hline SMV-G7d & $16 / 30$ & $0 / 27$ & $0 / 26$ & ND & ND \\
\hline SMV-JL1 & $4 / 4$ & $0 / 8$ & ND & $0 / 8$ & $0 / 8$ \\
\hline SMV-JL3 & $4 / 4$ & $0 / 8$ & ND & $1 / 8^{c}$ & $0 / 8$ \\
\hline
\end{tabular}

a Total number of plants systemically infected/total numbers of plants mechanically inoculated with sap derived from infected tissues. Plants were evaluated for the presence of systemic symptoms at 21 days postinoculation. Asymptomatic plants were assayed by enzyme-linked immunosorbent assay. b $\mathrm{ND}=$ not done.

c Asymptomatic infection detected by ELISA as well as reverse transcription PCR; however, SMV was not recovered from the tissues following backinoculation of sap onto susceptible soybean cultivar Williams. 
inoculated broad bean cultivars (Table 2). Collectively, these observations suggest that broad bean is indeed a host to SMV; however, infection of SMV in broad bean is subliminal and the virus is incapable of moving systemically.

The data presented in Figure 1B confirm findings by Abe et al. (2019) showing that cultivated soybean Williams is a host to CIYVV-No. 30 GUS; however, based on the lack of GUS expression in noninoculated leaves, the virus is incapable of moving systemically in this host. On the other hand, ClYVV-No. 30 GUS moved systemically in wild soybean line B01167 and broad bean cultivar Windsor (Fig. 1B). ClYVV-No. 30 was also capable of infecting systemically broad bean cultivar Robin Hood (Table 1).

HC-Pro from SMV-N shares $48.9 \%$ amino acid identity with that of CIYVV-No. 30. The SMV-N genome is 9,588 nucleotides long, whereas that of ClYVV-No. 30 is 9,584 nucleotides long (Supplementary Table S2). The encoded polyprotein of SMV-N is 3,066 amino acids long, whereas that of ClYVV-No. 30 is 3,072 amino acids long. Overall, the two genomes shared 55.1 and $46.8 \%$ nucleotide and amino acid sequence identity, respectively. Phylogenetic analysis suggests that SMV is distantly related to ClYVV among potyvirus species whose infections have been reported in soybean (Abe et al. 2019). There were significant differences among cistrons of the two viruses at the nucleotide and amino acid levels (Supplementary Table S2). At the amino acid level, P1 and NIb had the lowest and highest percent identities (20.3 and $60.2 \%$, respectively) (Supplementary Table S2). The sequence identity between HC-Pro from SMV-N with that of ClYVV-No. 30 was $48.9 \%$ at the amino acid level (Fig. 2; Supplementary Table S2). However, the percent identity at the nucleotide level was slightly higher at 55.6\% (Supplementary Fig. S1; Supplementary Table S2). Interestingly, HC-Pro from ClYVV-No. 30 with that of ClYVV-Gm that systemically infects cultivated soybean in South Korea (Shin et al. 2014) (GenBank accession KF975894) differed by four amino acids (Supplementary Fig. S2). It should be noted that the percent identity of HC-Pro between ClYVV-No. 30 and that of ClYVV-Gm at nucleotide and amino acid levels was 94.8 and $99.1 \%$, respectively (Supplementary Table S3).

Precise exchange of HC-Pro cistron between SMV-N and CIYVV-No. 30 resulted in viable chimeric viruses in infection but did not influence host range specificity. To determine whether HC-Pro cistrons from SMV-N and that of ClYVVNo. 30 are functionally compatible in infection and whether they carry the determinant(s) for systemic infection in cultivated soybean and broad bean, respectively, the two cistrons were precisely switched. As shown in Figure 3A, HC-Pro exchanges did not alter the amino acid sequences located at the $\mathrm{C}$-terminal cleavage site of HC-Pro at the junction with P3 for both recombinant viruses. However, amino acid sequences at the $\mathrm{C}$ termini of $\mathrm{P} 1$ at the cleavage sites differed between the two viruses. Regardless, this difference had no bearing on the composition of amino acid sequences of HC-Pro from the recombinant viruses; hence, the exchanges of HC-Pro cistrons between SMV-N and ClYVV-No. 30 within the context of the resultant chimeric viruses were precise.

When recombinant viruses were inoculated biolistically onto cultivated soybean Williams, broad bean Windsor, and wild soybean line B01167, both chimeras were viable in infection (Fig. 3B). The viability of HC-Pro chimeric potyviruses is in line with previous publications (Carbonell et al. 2012; Maliogka et al. 2012). However, the pathogenicity of SMV-N/ClYVV-No. $30 \mathrm{HC}$-Pro and ClYVV-No. 30/SMV-N HC-Pro did not differ from those of the parental viruses (compare Figs. 3B and 4 with Fig. 1A and B and Table 1). The recombinant SMV-N/ClYVV-No. 30 HC-Pro, similar to SMV-N, moved systemically in cultivated soybean Williams as well as wild soybean line B01167, but not in broad bean cultivar Windsor (Fig. 4A). On soybean Williams, similar to wild-type SMV-N, it induced severe mottling of leaves and stunting of the plants whereas on wild soybean line B01167 it caused severe symptoms including leaf necrosis and stunting. On the other hand, the recombinant ClYVV-No. 30/SMV-N HC-Pro, similar to ClYVV-No. 30, moved systemically in broad bean cultivar Windsor and wild soybean line B01167; however, it failed to infect systemically cultivated soybean Williams (Fig. 4B). Its symptoms on broad bean Windsor were more severe than ClYVV-No. 30 and included severe systemic necrosis of leaves (Fig. 4B), tip necrosis, stem necrosis, and eventually death of the infected plants (data not shown). However, on wild soybean line B01167, it induced severe systemic mottling of leaves with no necrosis (Fig. 4B). Similar results were obtained when progeny viruses derived from molecularly cloned recombinant viruses were mechanically inoculated onto these plants (Table 3).

HC-Pro from CIYVV-No. 30 did not confer virulence to SMV-N on a recombinant inbred soybean line containing the $R s v 1$-derived resistance factors. L943 $(-3 g G 2)$ is a soybean RIL derived from a cross between SMV-resistant PI96983 (Rsv1) and SMV-susceptible soybean Lee68 ( $r s v 1)$ (Hayes et al. 2004; Wen et al. 2013). Infection by wild-type SMV-N on L943 $(-3 g G 2)$ is

N (309) SQNPEAQFF-RGWKKVFDKMPPHVENHECTTDFTNEQCGELAAAI SQSI FPVKKLSCKQCRQHI - KHLSW No.30 (303) SA---GDLFWKGYNQTEI DNRPKDI GHTCTSDL NVI QCGSVMAL MTLALFPCGRI TCKE CVEDFHNQNNR

N (377) EEYKQ---FLLAHMGCHGPEWETFQEI DGMR---- - YVKRVI ETSTAENASLQTSLEI VRLTQNYKSTHM No.30 (370) ERYARTERELSQAMTLLA---QTYPEFKHSRDI LQLFRERLSMENSNAEACVETNKAITSLTE-- - - TPF

N (439) L QI QDI NKALMK GPSVTQSELEQASKQLLAMTQWWKNHMTLTDEDALKVFRNKRSSKALLNPSLLCDNQL No.30 (433) NHI RKI NE VLLRYGSLTNDEVGVASASLLEI TRYI RNRTDSI QRNDLSKERNKI SSKTHI NLDLMCDNQL

N (509) DKNGNFVWGERGRHSKRFF ANYFEEVVPSEGYSKYVI RKNPNGQRELAI GSLI VPLDFERARMALQGKSV No.30 (503) DKNANFMWGQRAYHAKRFL SNYFSVI DPSE GYDKFI NRKLPNGTRELATGRLI VPTNFESFRDQMKGTMV

N (579) TREPI TMSCI SRQDGNFVYPCCCVTHDDGKAFYSELRSPTKRHLVI GT SGDPKYI DLPATDADRMYI AKE No.30 (573) DNRPI GKECVSRVKGAFCYPCCCTTDDI GNAI LSEFKMPTKY HLVLGGQE AAKYI ELPSDSS GMMYI AKD

N (649) GFCYLNI FLAML VNVNEDEAKDFTKMVRDVIVPRLGKWPTMLDVATAAYMLTVFHPETRNAELPRI LVDH No.30 (643) GYCHI NI FFAML VNVSEDKSKDF TKMVRDQIMPKL GQWPTMLDVATACWYLTVWFPDTLSAELPRI LVDH

N (719) ACQTMHVI DSFGSLTVGYHVLKAGTVNQLI QFASNDLQSE MKFYRVG No.30 (713) KLSTMHVLDSYGSI STGYHVLKANI VSQLI KFASDDLESDLKFYRVG

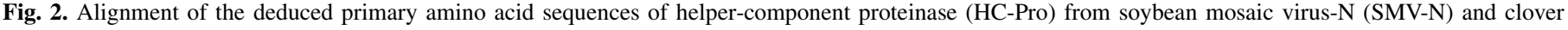

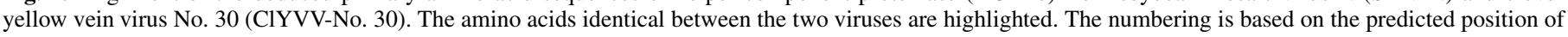

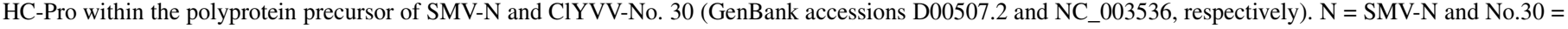
CIYVV-No. 30. 
restricted to limited foci in the inoculated leaves and the avirulence determinant(s) has been mapped to SMV strain-specific HC-Pro (Wen et al. 2013). On the other hand, infection by ClYVV-No. 30 in L943 (-3gG2), similar to infection in all other cultivated soybean genotypes, is also restricted to limited foci (Abe et al. 2019). It should be noted that inoculation of two SMV-N susceptible soybean cultivars, Lee68 (the susceptible parent of L943 [-3gG2]) and Williams, with the recombinant SMV-N/ClYVV-No. 30 HC-Pro resulted in systemic infection (Fig. 4A; Table 3). Surprisingly, when SMV-N/CIYVV-No. 30 HC-Pro was biolistically inoculated onto unifoliate leaves of L943 (-3gG2), none of the inoculated RIL L943 $(-3 g G 2)$ showed any sign of systemic infection and the virus was undetectable by ELISA in the noninoculated leaves. Mechanical inoculation of L943 $(-3 g G 2)$ with progeny viruses derived from bilistically inoculated Williams with molecularly cloned SMV-N/ ClYVV-No. 30 HC-Pro also yielded similar results and the virus was undetectable by ELISA in noninoculated leaves of any of 76 mechanically inoculated plants (Table 3 ). It should be noted that previously it has been shown that precise replacement of HC-Pro from SMV-N with the HC-Pro from SMV-G7 or SMV-G7d, both virulent strains on L943 (-3gG2) resulted in gain of virulence by SMV-N/G7 HC-Pro or SMV-N/G7d HC-Pro on L943 (-3gG2) (Wen et al. 2013). These observations suggest that in L943 (-3gG2) the HC-Pro from ClYVV-No. 30 is functionally equivalent to that of SMV-N HC-Pro because it failed to confer virulence to SMV-N/ ClYVV-No. 30 chimera.

\section{DISCUSSION}

For a virus to infect a plant systemically, it should have evolved all of the determinants necessary to interact successfully with various host factors to complete critical steps in the infection cycle (Hull 2014). Furthermore, as plants have evolved mechanisms to counter viral invasion, competent viruses have acquired determinants to evade plant defense systems mediated by innate immunity and passive or active mechanisms (Li and Ding 2006; Mandadi and Scholthof 2013; Whitham and Hajimorad 2016). On the other hand, for a plant to serve as a permissive host to a virus following transmission and to allow for systemic invasion, it should lack dominant or recessive resistance genes directed against the invading virus. In addition, such a plant should possess all of the necessary susceptibility factors for compatible interactions with cognate viralderived elements (Hull 2014; Revers and Nicaise 2014; Sanfaçon
2015). Thus, the inability of a virus to infect a plant and to move systemically could be either a result of the lack of genetic determinants or a consequence of an evolved specific resistance mechanism in the host plant.

One of our aims in this study was to determine whether broad bean is a host to SMV. To date, there has been no published report for isolation of SMV from systemically infected broad bean under field or experimental conditions (Golnaraghi et al. 2004; Hunst and Tolin 1982). The observation that inoculation with SMV-N GUS led to the detection of GUS expression in the inoculated leaves at 21 DPI suggests that broad bean indeed supports the replication of SMV-N locally. It worth noting that previous studies showed that GUS expression in the inoculated leaves following biolistic delivery of SMV-N GUS after 21 DPI is not a consequence of passive transcription and translation of the delivered plasmid and is indicative of virus replication (Abe et al. 2019; Khatabi et al. 2012; Wang et al. 2015; Wen and Hajimorad 2010; Wen et al. 2013; Zhang et al. 2009).

As broad bean supports SMV replication locally, evidenced by expression of GUS, it is a host (Hull 2014). However, because of a lack of determinant(s), SMV is incapable of moving long distance. To identify the determinant(s) via a comparative genomic approach, a well-adapted naturally occurring SMV strain isolated from a systemically infected broad bean is needed. However, because of the absence of such a strain, we instead set out to explore the ability of HC-Pro from ClYVV-No. 30 that systemically infects efficiently various broad bean genotypes (Abe et al. 2019; Bos et al. 1977; Foster and Musgrave 1985; Masuta et al. 2000; Munro 1981; Nakahara et al. 2011; Sasaya et al. 1997). It should be noted that potyviruses do not have a dedicated movement protein and a number of viral-encoded proteins are involved in the movement processes. These include P1, HC-Pro, P3, P3N-PIPO, cytoplasmic inclusion, 6K2, VPg, and CP (Adams et al. 2012; Revers and Garcia 2015; Schaad et al. 1997; Spetz and Valkonen 2004; Vassilakos et al. 2015; Wen and Hajimorad 2010).

In this study, we focused on HC-Pro because of its multifunctional role in the life cycle of potyviruses, its established function in systemic movement, and its involvement in pathogenicity and virulence (Hajimorad et al. 2008, 2011; Kasschau et al. 1997; Khatabi et al. 2013; Rolland et al. 2009; Wen et al. 2013). In addition, it has been suggested that HC-Pro is a relevant factor in host range specificity (Carbonell et al. 2012; Sáenz et al. 2002). To determine whether HC-Pro from ClYVV-No. 30 can replace that of
A

SMV-N
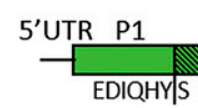

HC-Pro

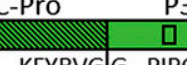

CIYW-No.30 $\frac{\text { 5'UTR P1 }}{\text { SRIREFIS }}$

HC-Pro

\begin{abstract}
KFYRVG G PIPO
\end{abstract}
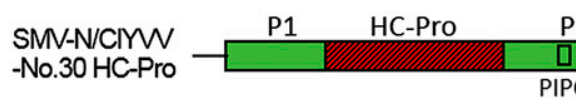

P3

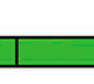

$\mathrm{C}$

CIMN-No.30/
SMV-N HC-Pro

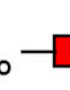

P1 HC-Pro

P1

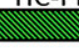

\footnotetext{
3. A, Schematic representation of genome of pa
}

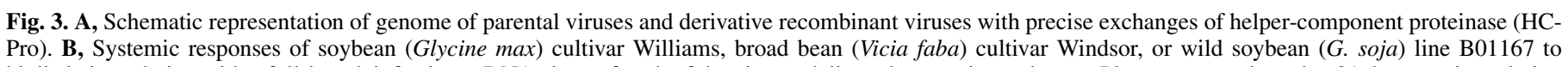

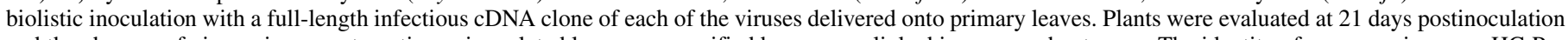

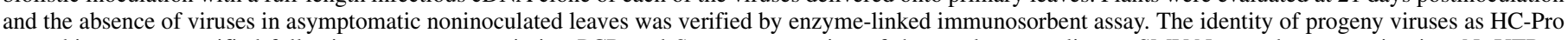

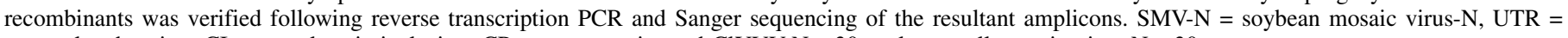
untranslated region, $\mathrm{CI}=$ cytoplasmic inclusion, $\mathrm{CP}=$ coat protein, and CIYVV-No. $30=$ clover yellow vein virus No. 30 . 
SMV-N successfully in infection, and also complement systemic movement of SMV-N in broad bean, the entire cistron of SMV-N was replaced precisely with that of ClYVV-No. 30. SMV-N/ ClYVV-No. 30 HC-Pro was viable in infection; however, it did not move systemically in broad bean. This suggests that the determinant(s) of CIYVV-No. 30 for systemic movement in this host resides elsewhere, or an additional viral-encoded protein is also
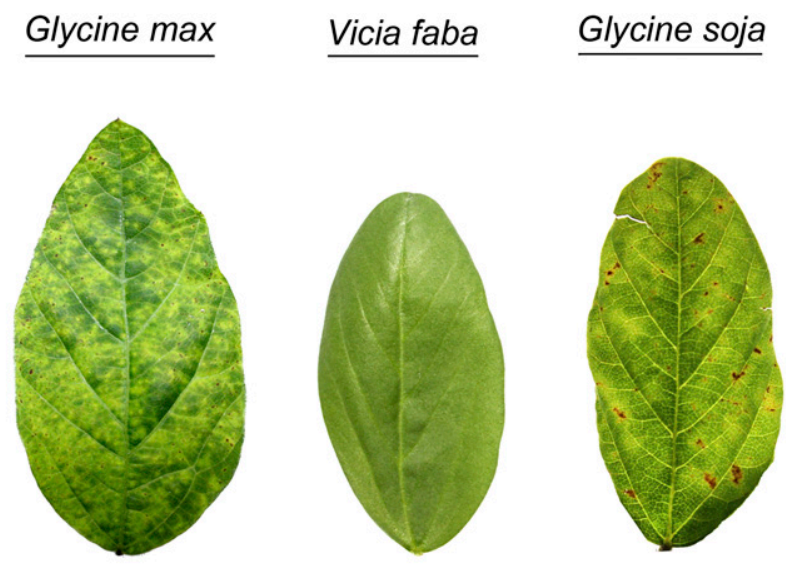

B
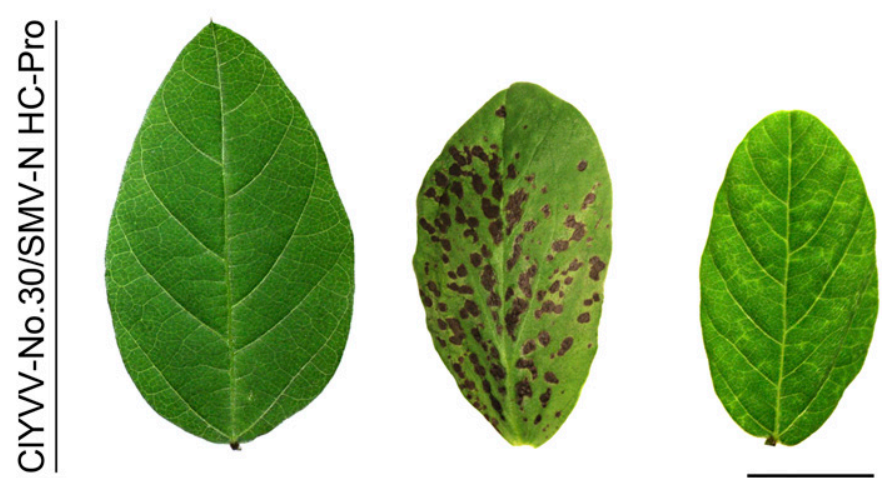

Fig. 4. Systemic responses of soybean (Glycine max) cultivar Williams, broad bean (Vicia faba) cultivar Windsor, or wild soybean (G. soja) line B01167 to biolistic inoculation with $\mathbf{A}$, soybean mosaic virus-N (SMV-N)- or B, clover yellow vein virus No. 30 (ClYVV-No. 30)-derived helper-component proteinase (HC-Pro) recombinant viruses. For inoculation, a full-length infectious cDNA clone of recombinant HC-Pro viruses was delivered biolistically into fully developed attached primary leaves of approximately 2 -week-old seedlings. The inoculated plants were maintained at $22^{\circ} \mathrm{C}$ until a leaflet from noninoculated leaves was photographed at 21 days postinoculation. The identity of progeny viruses as HC-Pro recombinants was verified following reverse transcription PCR and Sanger sequencing of the resultant amplicons. Absence of viruses in asymptomatic noninoculated leaves was verified by enzyme-linked immunosorbent assay. Scale bar $=2 \mathrm{~cm}$. needed to complement HC-Pro function in systemic movement. In addition to HC-Pro, other SMV-encoded proteins have a role in mediating movement of potyviruses within the host (Hull 2014). This is further supported by the observation that precise replacement of HC-Pro from ClYVV-No. 30 with that of SMV-N did not abolish systemic movement of this chimera in broad bean. However, ClYVV-No. 30/SMV-N HC-Pro did not move systemically in cultivated soybean. It is worth noting that the role of HC-Pro in the expansion of host range was also studied by Stenger and French (2004), in which HC-Pro from wheat streak mosaic virus (WSMV) was replaced with that of either oat necrotic mottle virus, agropyron mosaic virus, hordeum mosaic virus, tobacco etch virus (TEV), or turnip mosaic virus. However, in all of these exchanges, two amino acids from WSMV HC-Pro at the $\mathrm{N}$ terminus were not replaced. Atreya and Pirone (1993) also replaced HC-Pro from tobacco vein mottling virus (TVMV) with that of zucchini yellow mosaic virus (ZYMV); however, the exchange was not complete, as five amino acids located at the N-terminal portion of TVMV HCPro were not replaced. Nevertheless, in these experiments, the host range specificity of WSMV- and TVMV-derived chimeras were not altered following partial exchanges of HC-Pro (Atreya and Pirone 1993; Stenger and French, 2004). In the current study, however, we exchanged precisely the entire HC-Pro cistron between SMV-N and ClYVV-No. 30 in a reciprocal manner.

In our study, we did not address the genetic basis of resistance in broad bean that restricts systemic movement of SMV-N. Thus, it remains unknown whether resistance to systemic movement of SMV-N is mediated by a passive or an active mechanism. Interestingly, the symptomless phenotype of resistance against SMV-N in broad bean resembles those mediated by $R s v 1$-derived resistance factors in soybean RIL L943 $(-3 G g 2)$ or the $R s v 4$ gene in soybean (Khatabi et al. 2012; Wang et al. 2015; Wen et al. 2013). It should be noted that the determinants of SMV interacting with the $R s v 1$-derived resistance factors in soybean RIL L943 $(-3 G g 2)$ reside on HC-Pro, whereas those interacting with Rsv4 reside on P3 (Chowda-Reddy et al. 2011; Khatabi et al. 2012; Wang et al. 2015).

Abe et al. (2019) attributed the inability of ClYVV-No. 30 to move systemically in cultivated soybeans to the presence of a resistance locus containing a recessive gene(s). Interestingly, the phenotype of resistance to ClYVV-No. 30 in cultivated soybean resembles that of SMV-N in broad bean (Abe et al. 2019). However, the determinant(s) of ClYVV-No. 30 interacting with this resistance factor(s) was not determined by Abe et al. (2019). In this study, we ruled out the HC-Pro from ClYVV-No. 30 as the cognate factor interacting with the resistance locus in cultivated soybean. Thus, avirulence determinants of ClYVV-No. 30 reside outside of HCPro. It should be noted that the $6 \mathrm{~K} 1$ and nuclear inclusion protein aproteinase (NIa-Pro) regions of CIYVV-No. 30 share 100\% identity at the nucleotide and amino acid levels with those of CIYVV-Gm, which is a naturally evolved strain capable of systemic infection in cultivated soybeans (Shin et al. 2014; Supplementary Figs. S3 and S4). NIa-Pro as well as $6 \mathrm{~K} 1$ proteins are both involved in determining the host range of other potyviruses (Chen et al. 2008; Sáenz et al. 2000). Excluding 6K1 and NIa-Pro, there are amino acid

TABLE 3. Systemic responses of host genotypes to inoculation with soybean mosaic virus-N (SMV-N)- or clover yellow vein virus No. 30 (ClYVV-No. 30 )derived helper-component proteinase (HC-Pro) chimeras

\begin{tabular}{|c|c|c|c|c|c|}
\hline \multirow[b]{3}{*}{ Virus } & \multicolumn{5}{|c|}{ Host genotype $(n)^{\mathrm{a}}$} \\
\hline & \multicolumn{3}{|c|}{ Glycine $\max$} & \multirow{2}{*}{$\begin{array}{c}\text { Vicia faba } \\
\text { Windsor }\end{array}$} & \multirow{2}{*}{$\frac{G \text {. soja }}{\text { B01167 }}$} \\
\hline & Williams & Lee68 & L943 $(-3 g G 2)$ & & \\
\hline ClYVV-No. 30/SMV-N-HC-Pro & $0 / 8(0 / 19)$ & (ND) & (ND) & $8 / 8(15 / 18)$ & $8 / 8$ \\
\hline
\end{tabular}

a Total number of plants systemically infected/total numbers of plants biolistically inoculated on primary leaves with infectious cDNA clones. Plants were evaluated for presence of systemic symptoms at 21 days postinoculation. Asymptomatic plants were assayed by enzyme-linked immunosorbent assay.

${ }^{b}$ Numbers shown in parentheses indicate the total number of systemically infected plants/total number of plants inoculated mechanically with progeny viruses in sap extract derived from systemically infected leaves of biolistically inoculated Williams or Windsor. 
differences between all of the other encoded proteins of ClYVV-No. 30 compared with those of ClYVV-Gm, with the percent amino acid sequence identities varying from 94.1 to $99.8 \%$ (Supplementary Table S3). The P1 cistron is the most variable region between the two viruses, with 92.4 and $94.1 \%$ sequence identity at the nucleotide and amino acid levels, respectively (Supplementary Table S3). In general, the P1 cistron is the most variable region among potyviruses, which has led to assumptions that it is a key factor in host adaptation and evolution (Adams et al. 2005; Valli et al. 2007). However, experimental evidence in support of this hypothesis is limited (Salvador et al. 2008b; Shan et al. 2018). In the search for host range determinants of SMV-N and CIYVV-No. 30, future research will focus on the role of the P1 cistron.

The observation that some potyvirus members (e.g., bean yellow mosaic virus [BYMV]) have an extensive natural host range encompassing both dicots and monocots, whereas others (e.g., SMV) have a very narrow host range is intriguing (Bos 1972; Hajimorad et al. 2018; Kehoe et al. 2014). SMV and BYMV both have a single-stranded RNA genome and are naturally transmitted by seed as well as in a nonpersistent manner by aphids. Thus, it is unlikely that replication strategy and mode of transmission has much of influence on the generation of variation and consequently evolution toward host specialization. Recombination has been reported for both of these viruses, which has the potential to generate genome variation and possibly lead to host adaptation (Gagarinova et al. 2008; Kehoe et al. 2014; Wylie and Jones 2009). Thus, it seems that the determinants of host range specificity of potyviruses are complex. In addition to HC-Pro, other exchanges of genomic parts among potyviruses included $\mathrm{P} 1$ between plum pox virus (PPV) and TVMV (Salvador et al. 2008b), CP between PPV and ZYMV (Tóbiás et al. 2001), and CP between ZYMV and watermelon mosaic virus (Ullah et al. 2003). None of these exchanges led to the expansion of host ranges of the experimentally generated recombinant viruses. However, replacement of the PPV P1 cistron with that of TVMV resulted in a loss of infectivity of the chimera in the PPV-specific host, highlighting the relevance of P1 in host adaptation (Salvador et al. 2008b). Regardless, the results from these experiments revealed the importance of specific potyviral encoded proteins in host adaptation and requirements for the involvement of multiple viral-encoded proteins in determining the host range (Calvo et al. 2014; Carbonell et al. 2012; Dallot et al. 2001; Rajamaki and Valkonen 1999; Sáenz et al. 2000; Salvador et al. 2008a; Shan et al. 2018; Vassilakos et al. 2015). The involvement of multiple viral proteins in host adaptation points to multiple and overlapping functions that each of the viral-encoded proteins have in the potyviral infection cycle (Kasschau and Carrington 2001; Rojas et al. 1997). Even to overcome resistance mediated by dominant resistance loci, multiple potyviral encoded proteins are involved in some instances (Chu et al. 1997; Eggenberger et al. 2008; Hajimorad et al. 2008, 2011; Jenner et al. 2002; Krause-Sakate et al. 2005; Wen et al. 2013). These observations suggest that a plant virus must overcome many barriers in order to infect a host systemically, which requires multiple changes within viral genomes and the proteins involved (Dawson and Hilf 1992).

The finding that HC-Pro from ClYVV-No. 30, similar to that of SMV-N, did not confer virulence to the recombinant SMV-N/ CIYVV-No. 30 HC-Pro on RIL L943 (-3gG2) was unexpected. This recombinant virus systemically infected Lee 68, which is the susceptible parental soybean genotype of RIL L943 (-3gG2) (Table 3 ). It should be noted that SMV-N causes only local infection in RIL L943 (-3gG2), which contains five genes (IeG30, $5 g G 3$, $I e G 15,6 g G 9$, and $I g G 4)$ derived from the complex multigenic Rsv 1 locus of the parental SMV-resistant soybean genotype PI96983 (Hayes et al. 2004; Wen et al. 2013). However, it remains unknown whether lack of function of HC-Pro from ClYVV-No. 30 within the context of SMV-N/ClYVV-No. 30 HC-Pro in RIL L943 (-3gG2) is a consequence of recognition by any of these $R s v 1$-derived resistance genes. It should be pointed out that recognition of different potyvirus species by resistance genes located within a single host locus is not unusual. The restricted TEV movement (RTM)mediated resistance identified originally in Arabidopsis thaliana against TEV also recognizes other potyviruses, including PPV and lettuce mosaic virus (Decroocq et al. 2009). Interestingly, two recessive alleles, $b c-u$ and $b c-3$, in common bean (Phaseolus vulgaris) when present together in a single host confer resistance to multiple strains as well as multiple potyviruses (Feng et al. 2015). In common bean, two recessive genes, $b c-1$ and $b c-2$, also confer resistance to bean common mosaic virus and bean common mosaic necrosis virus by preventing systemic spread (Feng et al. 2017, 2018). Recessive resistance genes against CIYVV in A. thaliana or soybean have already been identified or mapped (Abe et al. 2019; Sato et al. 2005). The possibility that HC-Pro from ClYVV-No. 30 may be recognized by one of the Rsvl-derived genes in soybean warrants additional study because it could provide a new source for $R$ genes against ClYVV.

\section{LITERATURE CITED}

Abe, J., Wang, Y., Yamada, T., Sato, M., Ono, T., Atsumi, G., Abe, J., Hajimorad, M. R., and Nakahara, K. S. 2019. Recessive resistance governed by a major quantitative trait locus restricts clover yellow vein virus in mechanically but not graft-inoculated cultivated soybeans. Mol. PlantMicrobe Interact. 32:1026-1037.

Adams, M. J., Antoniw, J. F., and Fauquet, C. M. 2005. Molecular criteria for genus and species discrimination within the family Potyviridae. Arch. Virol. 150:459-479.

Adams, M. J., Zerbini, F. M., French, R., Stenger, D. C., and Valkonen, J. P. T. 2012. Potyviridae. Pages 1069-1089 in: Virus Taxonomy: Ninth Report of the International Committee on Taxonomy of Viruses. A. M. Q. King, M. J. Adams, E. B. Carstens, and E. J. Lefkowitz, eds. Elsevier/Academic Press, London, UK.

Adams, S. E., Jones, R. A. C., and Coutts, R. H. A. 1986. Expression of potato virus $\mathrm{X}$ resistance gene $\mathrm{Rx}$ in potato leaf protoplasts. J. Gen. Virol. 67: 2341-2345.

Atreya, C. D., and Pirone, T. P. 1993. Mutational analysis of the helper component-proteinase gene of a potyvirus: Effects of amino acid substitutions, deletions, and gene replacement on virulence and aphid transmissibility. Proc. Natl. Acad. Sci. USA 90:11919-11923.

Atsumi, G., Suzuki, H., Miyashita, Y., Choi, S. H., Hisa, Y., Rihei, S., Shimada, R., Jeon, E. J., Abe, J., Nakahara, K. S., and Uyeda, I. 2016. P3NPIPO, a frameshift product from $P 3$, pleiotropically determines the virulence of clover yellow vein virus in both resistant and susceptible peas. J. Virol. 90:7388-7404.

Bendahmane, A., Kanyuka, K., and Balcombe, D. C. 1999. The Rx gene from potato controls separate virus resistance and cell death responses. Plant Cell 11:781-791.

Bernard, R. L., Nelson, R. L., and Creemens, C. R. 1991. USDA soybean genetic collection: Isoline collection. Soybean Genet. Newsl. 18:27-57.

Bos, L. 1972. Soybean Mosaic Virus. CMI/AAB Description of Plant Viruses, No. 93. Commonwealth Mycological Institute/Association of Applied Biologists, Kew, Surrey, UK.

Bos, L., Lindsten, K., and Maat, D. Z. 1977. Similarity of clover yellow vein virus and pea necrosis virus. Neth. J. Plant Pathol. 83:97-108.

Calvo, M., Malinowski, T., and Garcia, J. A. 2014. Single amino acid changes in the 6K1-CI region can promote the alternative adaptation of Prunus-and Nicotiana-propagated Plum pox virus C isolates to either host. Mol. PlantMicrobe Interact. 27:136-149.

Carbonell, A., Dujovny, G., Garcia, J. A., and Valli, A. 2012. The Cucumber vein yellowing virus silencing suppressor $\mathrm{P} 1 \mathrm{~b}$ functionally replaces $\mathrm{HC}$-Pro in Plum pox virus infection in a host-specific manner. Mol. Plant-Microbe Interact. 25:151-164.

Carbonell, A., Maliogka, V. I., Perez, J. d. J., Salvador, B., San Leon, D., García, J. A., and Simón-Mateo, C. 2013. Diverse amino acid changes at specific positions in the N-terminal region of the coat protein allow Plum pox virus to adapt to new hosts. Mol. Plant-Microbe Interact. 26: 1211-1224.

Charlier, N., Molenkamp, R., Leyssen, P., Vandamme, A.-M., De Clercq, E., Bredenbeek, P., and Neyts, J. 2003. A rapid and convenient variant of fusion-PCR to construct chimeric flaviviruses. J. Virol. Methods 108:67-74.

Chen, K.-C., Chiang, C.-H., Raja, J. A. J., Liu, F.-L., Tai, C.-H., and Yeh, S.-D. 2008. A single amino acid of NIaPro of Papaya ringspot virus determines host specificity for infection of papaya. Mol. Plant-Microbe Interact. 21: 1046-1057. 
Cheng, H., Yang, H., Zhang, D., Gai, J., and Yu, D. 2010. Polymorphisms of soybean isoflavone synthase and flavanone 3-hydroxylase genes are associated with soybean mosaic virus resistance. Mol. Breed. 25:13-24.

Choi, S. H., Hagiwara-Komoda, Y., Nakahara, K. S., Atsumi, G., Shimada, R., Hisa, Y., Naito, S., and Uyeda, I. 2013. Quantitative and qualitative involvement of P3N-PIPO in overcoming recessive resistance against clover yellow vein virus in pea carrying the cyv1 gene. J. Virol. 87:7326-7337.

Chowda-Reddy, R. V., Sun, H., Chen, H., Poysa, V., Ling, H., Gijzen, M., and Wang, A. 2011. Mutations in the P3 protein of Soybean mosaic virus G2 isolates determine virulence on Rsv4-genotype soybean. Mol. PlantMicrobe Interact. 24:37-43.

Chu, M., Lopez-Moya, J. J., Llave-Correas, C., and Pirone, T. P. 1997. Two separate regions in the genome of the tobacco etch virus contain determinants of the wilting response of Tabasco pepper. Mol. Plant-Microbe Interact. 10:472-480.

Chung, B. Y.-W., Miller, W. A., Atkins, J. F., and Firth, A. E. 2008. An overlapping essential gene in the Potyviridae. Proc. Natl. Acad. Sci. USA 105:5897-5902.

Cronin, S., Verchot, J., Haldeman-Cahill, R., Schaad, M. C., and Carrington, J. C. 1995. Long-distance movement factor: A transport function of the potyvirus helper component proteinase. Plant Cell 7:549-559.

Dallot, S., Quiot-Douine, L., Saenz, P., Cervera, M. T., Garcia, A. J., and Quiot, J.-B. 2001. Identification of Plum pox virus determinants implicated in specific interactions with different Prunus spp. Phytopathology 91:159-164.

Dawson, W. O., and Hilf, M. E. 1992. Host-range determinants of plant viruses. Annu. Rev. Plant Physiol. Plant Mol. Biol. 43:527-555.

de Groot, S., Mailund, T., Lunter, G., and Hein, J. 2008. Investigating selection on viruses: A statistical alignment approach. BMC Bioinformatics 9:304.

Decroocq, V., Salvador, B., Sicard, O., Glasa, M., Cosson, P., Svanella-Dumas, L., Reverse, F., Garcia, J. A., and Candresse, T. 2009. The determinant of potyvirus ability to overcome the RTM resistance of Arabidopsis thaliana maps to the N-terminal region of the coat protein. Mol. Plant-Microbe Interact. 22:1302-1311.

Eggenberger, A. L., Hajimorad, M. R., and Hill, J. H. 2008. Gain of virulence on Rsv1-genotype soybean by an avirulent Soybean mosaic virus requires concurrent mutations in both P3 and HC-Pro. Mol. Plant-Microbe Interact. 21:931-936

Feng, X., Guzmán, P., Myers, J. R., and Karasev, A. V. 2017. Resistance to Bean common mosaic necrosis virus conferred by the $b c-1$ gene affects systemic spread of the virus in common bean. Phytopathology 107:893-900.

Feng, X., Myers, J. R., and Karasev, A. V. 2015. Bean common mosaic virus isolate exhibits a novel pathogenicity profile in common bean, overcoming the $b c-3$ resistance allele coding for the mutated elf4E translation initiation factor. Phytopathology 105:1487-1495.

Feng, X., Orellana, G. E., Myers, J. R., and Karasev, A. V. 2018. Recessive resistance to Bean common mosaic virus conferred by the $b c-1$ and $b c-2$ genes in common bean (Phaseolus vulgaris) affects long-distance movement of the virus. Phytopathology 108:1011-1018.

Foster, R. L. S., and Musgrave, D. R. 1985. Clover yellow vein virus in white clover (Trifolium repens) and sweet pea (Lathyrus odoratus) in the North Island of New Zealand. N. Z. J. Agric. Res. 28:575-578.

Gagarinova, A. G., Babu, M., Stromvik, M. V., and Wang, A. 2008. Recombination analysis of Soybean mosaic virus sequences reveals evidence of RNA recombination between distinct pathotypes. Virol. J. 5:143.

German-Retana, S., Candresse, T., Alias, E., Delbos, R.-P., and Le Gal, O. 2000. Effects of green fluorescent protein or $\beta$-glucuronidase tagging on the accumulation and pathogenicity of a resistance-breaking Lettuce mosaic virus isolate in susceptible and resistant lettuce cultivars. Mol. PlantMicrobe Interact. 13:316-324.

Gibbs, A., and Ohshima, K. 2010. Potyviruses and the digital revolution. Annu. Rev. Phytopathol. 48:205-223.

Gibbs, A. J., Armstrong, J. S., and Gibbs, M. J. 2004. A type of nucleotide motif that distinguishes tabamovirus species more efficiently than nucleotide signature. Arch. Virol. 149:1941-1954.

Golnaraghi, A. R., Shahraeen, N., Pourrahim, R., Farzadfar, Sh., and Ghasemi, A. 2004. Occurrence and relative incidence of viruses infecting soybeans in Iran. Plant Dis. 88:1069-1074.

Hajimorad, M. R., Domier, L. L., Tolin, S. A., Whitham, S. A., and Saghai Maroof, M. A. 2018. Soybean mosaic virus: A successful potyvirus with a wide distribution but restricted natural host range. Mol. Plant Pathol. 19:1563-1579.

Hajimorad, M. R., Eggenberger, A. L., and Hill, J. H. 2003. Evolution of Soybean mosaic virus-G7 molecularly cloned genome in Rsv1-genotype soybean results in emergence of a mutant capable of evading Rsv1-mediated recognition. Virology 314:497-509.

Hajimorad, M. R., Eggenberger, A. L., and Hill, J. H. 2008. Adaptation of Soybean mosaic virus avirulent chimeras containing P3 sequences from virulent strains to Rsv1-genotype soybeans is mediated by mutations in HCPro. Mol. Plant-Microbe Interact. 21:937-946.
Hajimorad, M. R., and Hill, J. H. 2001. Rsv1-mediated resistance against Soybean mosaic virus- $\mathrm{N}$ is hypersensitive response-independent at inoculation site, but has the potential to initiate a hypersensitive response-like mechanism. Mol. Plant-Microbe Interact. 14:587-598.

Hajimorad, M. R., Wen, R.-H., Eggenberger, A. L., Hill, J. H., and Saghai Maroof, M. A. 2011. Experimental adaptation of an RNA virus mimics natural evolution. J. Virol. 85:2557-2564.

Hayes, A. J., Jeong, S. C., Gore, M. A., Yu, Y. G., Buss, G. R., Tolin, S. A., and Saghai Maroof, M. A. 2004. Recombination within a nucleotide-bindingsite/leucine-rich repeat gene cluster produces new variants conditioning resistance to soybean mosaic virus in soybeans. Genetics 166:493-503.

Hilf, M. E., and Dawson, W. O. 1993. The tobamovirus capsid protein functions as a host-specific determinant of long-distance movement. Virology 193:106-114.

Hull, R. 2014. Plant Virology. Academic Press, New York.

Hunst, P. I., and Tolin, S. A. 1982. Isolation and comparison of two strains of soybean mosaic virus. Phytopathology 72:710-713.

Ishibashi, K., Naito, S., Meshi, T., and Ishikawa, M. 2009. An inhibitory interaction between viral and cellular proteins underlies the resistance of tomato to nonadapted tobamoviruses. Proc. Natl. Acad. Sci. USA 106: 8778-8783.

Jenner, C. E., Tomimura, K., Ohshima, K., Hughes, S. L., and Walsh, J. A. 2002. Mutations in Turnip mosaic virus P3 and cylindrical inclusion proteins are separately required to overcome two Brassica napus resistance genes. Virology 300:50-59.

Kasschau, K. D., and Carrington, J. C. 2001. Long-distance movement and replication maintenance functions correlate with silencing suppression activity of potyviral HC-Pro. Virology 285:71-81.

Kasschau, K. D., Cronin, S., and Carrington, J. C. 1997. Genome amplification and long-distance movement functions associated with the central domain of tobacco etch potyvirus helper component-proteinase. Virology 228: 251-262.

Kehoe, M. A., Coutts, B. A., Buirchell, B. J., and Jones, R. A. 2014. Split personality of a Potyvirus: To specialize or not to specialize? PLoS One 9: e105770.

Khatabi, B., Fajolu, O. L., Wen, R.-H., and Hajimorad, M. R. 2012. Evaluation of North American isolates of Soybean mosaic virus for gain of virulence on $R s v$-genotype soybeans with special emphasis on resistance-breaking determinants on Rsv4. Mol. Plant Pathol. 13:1077-1088.

Khatabi, B., Wen, R.-H., and Hajimorad, M. R. 2013. Fitness penalty in susceptible host is associated with virulence of Soybean mosaic virus on Rsv1-genotype soybean: A consequence of perturbation of HC-Pro and not P3. Mol. Plant Pathol. 14:885-897.

Krause-Sakate, R., Redondo, E., Richard-Forget, F., Jadao, A. S., Houvenaghel, M.-C., German-Retana, S., Pavan, M. A., Candresse, T., Zerbini, F. M., and Gall, O. L. 2005. Molecular mapping of the viral determinants of systemic wilting induced by a Lettuce mosaic virus (LMV) isolate in some lettuce cultivars. Virus Res. 109:175-180.

Li, F., and Ding, S. W. 2006. Virus counterdefense: Diverse strategies for evading the RNA-silencing immunity. Annu. Rev. Microbiol. 60:503-531.

Lopez-Moya, J. J., Valli, A., and Garcia, J. A. 2009. Potyviridae. In: Encyclopedia of Life Sciences (ELS). John Wiley \& Sons Ltd., Chichester, UK.

Malapi-Nelson, M., Wen, R.-H., Ownley, B. H., and Hajimorad, M. R. 2009. Co-infection of soybean with Soybean mosaic virus and Alfalfa mosaic virus results in disease synergism and alteration in accumulation level of both viruses. Plant Dis. 93:1259-1264.

Maliogka, V. I., Calvo, M., Carbonell, A., Garcia, J. A., and Valli, A. 2012. Heterologous RNA-silencing suppressors from both plant- and animalinfecting viruses support plum pox virus infection. J. Gen. Virol. 93: 1601-1611.

Mandadi, K. K., and Scholthof, K. B. 2013. Plant immune responses against viruses: How does a virus cause disease? Plant Cell 25:1489-1505.

Masuta, C., Yamana, T., Tacahashi, Y., Uyeda, I., Sato, M., Ueda, S., and Matsumura, T. 2000. Development of clover yellow vein virus as an efficient, stable gene-expression system for legume species. Plant J. 23:539-546.

Mise, K., Allison, R. F., Janda, M., and Ahlquist, P. 1993. Bromovirus movement protein genes play a critical role in host specificity. J. Virol. 67: 2815-2825.

Munro, D. 1981. Clover yellow vein virus in broad bean. Australas. Plant Pathol. 10:61-62.

Nakahara, K. S., Kitazawa, H., Atsumi, G., Choi, S. H., Suzuki, Y., and Uyeda, I. 2011. Screening and analysis of genes expressed upon infection of broad bean with Clover yellow vein virus causing lethal necrosis. Virol. J. 8:355.

Padgett, H. S., and Beachy, R. N. 1993. Analysis of a tobacco mosaic virus strain capable of overcoming $N$ gene-mediated resistance. Plant Cell 5: 577-586.

Padgett, H. S., Watanabe, Y., and Beachy, R. N. 1997. Identification of the TMV replicase sequence that activates the $N$ gene-mediated hypersensitive response. Mol. Plant-Microbe Interact. 10:709-715. 
Poulicard, N., Pinel-Galzi, A., Traore, O., Vignols, F., Ghesquiere, A., Konate, G., Hebrard, E., and Fargette, D. 2012. Historical contingencies modulate the adaptability of Rice yellow mottle virus. PLoS Pathog 8:e1002482.

Rajamaki, M.-L., and Valkonen, J. P. T. 1999. The 6K2 protein and the VPg of potato virus A are determinants of systemic infection in Nicotiana physaloides. Mol. Plant Pathol. 12:1074-1081.

Revers, F., and Garcia, J. M. 2015. Molecular biology of potyviruses. Adv. Virus Res. 92:101-199.

Revers, F., and Nicaise, V. 2014. Plant resistance to infection by viruses. Pages 1-10 in: Encyclopedia of Life Sciences (ELS). John Wiley \& Sons Ltd., Chichester, UK.

Rojas, M. R., Zerbini, F. M., Allison, R. F., Gilbertson, R. L., and Lucas, W. J. 1997. Capsid protein and helper-component-proteinase function as potyvirus cell-to-cell movement proteins. Virology 237:283-295.

Rolland, M., Kerlan, C., and Jacquot, E. 2009. The acquisition of molecular determinants involved in potato virus $\mathrm{Y}$ necrosis capacity leads to fitness reduction in tobacco plants. J. Gen. Virol. 90:244-252.

Ryu, K. H., Kim, C.-H., and Palukaitis, P. 1998. The coat protein of cucumber mosaic virus is a host range determinant for infection of maize. Mol. PlantMicrobe Interact. 11:351-357.

Sáenz, P., Cervera, M. T., Dallot, S., Quiot, L., Quiot, J.-B., Riechmann, J. L., and Garcia, J. A. 2000. Identification of a pathogenicity determinant of Plum pox virus in the sequence encoding the C-terminal region of protein P3+6K1. J. Gen. Virol. 81:557-566.

Sáenz, P., Salvador, B., Simon-Mateo, C., Kasschau, K. D., Carrington, J. C., and Garcia, J. A. 2002. Host-specific involvement of the HC protein in the long-distance movement of potyviruses. J. Virol. 76:1922-1931.

Salvador, B., Delgadillo, M. O., Saenz, P., Garcia, J. A., and Simon-Mateo, C. 2008a. Identification of Plum pox virus pathogenicity determinants in herbaceous and wood hosts. Mol. Plant-Microbe Interact. 21:20-29.

Salvador, B., Saenz, P., Yanguez, E., Quiot, J. B., Quiot, L., Delgadillo, M. O., Garcia, J. A., and Simon-Mateo, C. 2008b. Host specific effect of P1 exchange between two potyviruses. Mol. Plant Pathol. 9:147-155.

Sanfaçon, H. 2015. Plant translation factors and virus resistance. Viruses 7: 3392-3419.

Sardaru, P., Sinausia, L., Lopez-Gonsalvez, Z., Zindovic, J., Sanchez, F., and Ponz, F. 2018. The apparent non-host resistance of Ethiopian mustard to a radish-infecting strain of turnip mosaic virus is largely determined by the C-terminal region of the P3 viral protein. Mol. Plant Pathol. 19:1984-1994.

Sasaya, T., Shimizu, T., Nozu, Y., Nishiguchi, M., Inouye, N., and Koganezawa, H. 1997. Biological, serological, and molecular variabilities of clover yellow vein virus. Phytopathology 87:1014-1019.

Sato, M., Nakahara, K., Yoshii, M., Ishikawa, M., and Uyeda, I. 2005. Selective involvement of members of the eukaryotic initiation factor $4 \mathrm{E}$ family in the infection of Arabidopsis thaliana by potyviruses. FEBS Lett. 579:1167-1171.

Schaad, M. C., Lellis, A. D., and Carrington, J. C. 1997. VPg of tobacco etch potyvirus is a host genotype-specific determinant for long-distance movement. J. Virol. 71:8624-8631.

Schoelz, J. E., and Shepherd, R. J. 1988. Host range control of cauliflower mosaic virus. Virology 162:30-37.

Seo, J.-K., Ohshima, K., Lee, H.-G., Son, M., Choi, H.-S., Lee, S.-H., Sohn, S.-H., and Kim, K.-H. 2009. Molecular variability and genetic structure of the population of Soybean mosaic virus based on the analysis of complete genome sequences. Virology 393:91-103.

Shan, H., Pasin, F., Tzanetakis, I. E., Simon-Moteo, C., Garcia, J. A., and Rodamilans, B. 2018. Truncation of a P1 leader proteinase facilitates potyvirus replication in a non-permissive host. Mol. Plant Pathol. 19:1504-1510.

Shaner, G., Stromberg, E. L., Lacy, G. H., Barker, K. R., and Pirone, T. P. 1992. Nomenclature and concepts of pathogenicity and virulence. Annu. Rev. Phytopathol. 30:47-66.

Shin, J. C., Kim, M. K., Kwak, H. R., Choi, H. S., Kim, J. S., Park, C. Y., Lee, S. H., and Cha, B. J. 2014. First report of Clover yellow vein virus on Glycine max in Korea. Plant Dis. 98:1283.
Spetz, C., and Valkonen, J. P. T. 2004. Potyviral 6K2 protein long-distance movement and symptom-induction functions are independent and hostspecific. Mol. Plant-Microbe Interact. 17:502-510.

Stenger, D. C., and French, R. 2004. Functional replacement of Wheat streak mosaic virus $\mathrm{HC}$-Pro with the corresponding cistron from a diverse array of viruses in the family Potyviridae. Virology 323:257-267.

Suehiro, N., Natsuaki, T., Watanabe, T., and Okuda, S. 2004. An important determinant of the ability of Turnip mosaic virus to infect Brassica spp. and/or Raphanus sativus is in its P3 protein. J. Gen. Virol. 85:2087-2098.

Tan, Z., Gibbs, A. J., Tomitaka, Y., Sanchez, F., Ponz, F., and Ohshima, K. 2005. Mutations in Turnip mosaic virus genomes that have adapted to Raphanus sativus. J. Gen. Virol. 86:501-510.

Tóbiás, I., Palkovics, L., Tzekova, L., and Balazs, E. 2001. Replacement of the coat protein gene of plum pox potyvirus with that of zucchini yellow mosaic potyvirus: Characterization of the hybrid potyvirus. Virus Res. 76:9-16.

Ullah, Z., Chai, B., Hammer, S., Raccah, B., Gal-On, A., and Grumet, R. 2003. Effect of substitution of the amino termini of coat proteins of distinct potyvirus species on viral infectivity and host specificity. Physiol. Mol. Plant Pathol. 63:129-139.

Valli, A., Lopez-Moya, J. J., and Garcia, J. A. 2007. Recombination and gene duplication in the evolutionary diversification of P1 protein in the family Potyviridae. J. Gen. Virol. 88:1016-1028.

Valli, A. A., Gallo, A., Rodamilans, B., López-Moya, J. J., and Antonio García, J. 2018. The HCPro from the Potyviridae family: An enviable multitasking helper component that every virus would like to have. Mol. Plant Pathol. 19: 744-763.

Vassilakos, N., Simon, V., Tzima, A., Johnsen, E., and Moury, B. 2015. Genetic determinism and evolutionary reconstruction of a host jump in a plant virus. Mol. Biol. Evol. 33:541-553.

Vijayapalani, P., Maeshima, M., Nagasaki-Takekuchi, N., and Miller, W. A. 2012. Interaction of the trans-frame potyvirus protein P3N-PIPO with host protein PCaP1 facilitate potyvirus movement. PLoS Pathog. 8:e1002639.

Wang, L., Eggenberger, A., Hill, J., and Bogdanove, A. J. 2006. Pseudomonas syringae effector $a v r B$ confers soybean cultivar-specific avirulence on Soybean mosaic virus adapted for transgene expression but effector avrPto does not. Mol. Plant-Microbe Interact. 19:304-312.

Wang, Y., Khatabi, B., and Hajimorad, M. R. 2015. Amino acid substitution in P3 of Soybean mosaic virus to convert avirulence to virulence on Rsv4genotype soybeans is influenced by the genetic composition of P3. Mol. Plant Pathol. 16:301-307.

Webby, R., Hoffmann, E., and Webster, R. 2004. Molecular constraints to interspecies transmission of viral pathogens. Nat. Med. 10:S77-S81.

Wen, R.-H., and Hajimorad, M. R. 2010. Mutational analysis of the putative pipo of soybean mosaic virus suggests disruption of PIPO protein impedes movement. Virology 400:1-7.

Wen, R.-H., Khatabi, B., Ashfield, T., Saghai Maroof, M. A., and Hajimorad, M. R. 2013. The HC-Pro and P3 cistrons of an avirulent Soybean mosaic virus are recognized by different genes at the complex Rsv1 locus. Mol. Plant-Microbe Interact. 26:203-215.

Whitham, S. A., and Hajimorad, M. R. 2016. Plant genetic resistance to viruses. Pages 87-113 in: Current Research Topics in Plant Virology. A. Wang and X. Zhou, eds. Springer International Publishing, Basel, Switzerland.

Wylie, S. J., Adams, M., Chalam, C., Kreuze, J., Lopes-Moya, J. J., Ohshima, K., Praveen, S., Rabenstein, F., Stenger, D., Wang, A., and Zerbini, F. M.; ICTV Report Consortium. 2017. ICTV virus taxonomy profile: Potyviridae. J. Gen. Virol. 98:352-354.

Wylie, S. J., and Jones, R. A. C. 2009. Role of recombination in the evolution of host specialization within Bean yellow mosaic virus. Phytopathology 99: 512-518.

Zhang, C., Hajimorad, M. R., Eggenberger, A. L., Tsang, S., Whitham, S. A., and Hill, J. H. 2009. Cytoplasmic inclusion cistron of Soybean mosaic virus serves as a virulence determinant on Rsv3-genotype soybean and a symptom determinant. Virology 391:240-248. 